\title{
Carbon isotope signatures of latest Permian marine successions of the Southern Alps suggest a continental runoff pulse enriched in land plant material
}

\author{
Sonja H. Kraus*, ${ }^{*}$, Rainer Brandner ${ }^{2}$, Christoph Heubeck ${ }^{1}$, Heinz W. Kozur ${ }^{3}$, Ulrich Struck ${ }^{4}$ \\ and Christoph Korte ${ }^{1,5}$ \\ ${ }^{1}$ Institut für Geologische Wissenschaften, Freie Universität Berlin, Malteserstr. 74-100, 12249 Berlin, Germany. \\ E-mail: sonja.kraus@t-online.de \\ ${ }^{2}$ Institut für Geologie und Paläontologie, Universität Innsbruck, Innrain 52, 6020 Innsbruck, Austria \\ ${ }^{3}$ Rézsü u. 83, 1029 Budapest, Hungary \\ ${ }^{4}$ Museum für Naturkunde, Leibniz-Institut für Evolutions- und Biodiversitätsforschung, Invalidenstraße 43, 10115 Berlin, Germany \\ ${ }^{5}$ Department of Geography and Geology \& Nordic Center for Earth Evolution (NordCEE), University of Copenhagen, Øster Voldgade 10, \\ 1350 Copenhagen K, Denmark
}

Received 28 March 2012

Accepted 26 October 2012

Published 20 February 2013

\section{Key Words}

Permian-Triassic boundary

Palaeoenvironmental changes

Land plant influx

\begin{abstract}
The latest Permian mass extinction, the most severe Phanerozoic biotic crisis, is marked by dramatic changes in palaeoenvironments. These changes significantly disrupted the global carbon cycle, reflected by a prominent and well known negative carbon isotope excursion recorded in marine and continental sediments. Carbon isotope trends of bulk carbonate and bulk organic matter in marine deposits of the European Southern Alps near the low-latitude marine event horizon deviate from each other. A positive excursion of several permil in $\delta^{13} \mathrm{C}_{\mathrm{org}}$ starts earlier and is much more pronounced than the short-term positive $\delta^{13} \mathrm{C}_{\text {carb }}$ excursion; both excursions interrupt the general negative trend. Throughout the entire period investigated, $\delta^{13} \mathrm{C}_{\text {org }}$ values become lighter with increasing distance from the palaeocoastline. Changing $\delta^{13} C_{\text {org }}$ values may be due to the influx of comparatively isotopically heavy land plant material. The stronger influence of land plant material on the $\delta^{13} \mathrm{C}_{\text {org }}$ during the positive isotope excursion indicates a temporarily enhanced continental runoff that may either reflect increased precipitation, possibly triggered by aerosols originating from Siberian Trap volcanism, or indicate higher erosion rate in the face of reduced land vegetation cover.
\end{abstract}

\section{Introduction}

The latest Permian mass extinction event, just preceding the Permian-Triassic boundary (PTB), was the severest mass extinction in Earth history. Approximately $90 \%$ of all marine and $75 \%$ of land species (e.g., Erwin 1994) became extinct, but many of these taxa reappeared as Lazarus taxa or successor taxa that are closely related to their Late Permian ancestors during the Anisian and Ladinian (Kozur 1998a, 1998b; see also Chen \& Benton 2012). The crisis, caused by dramatic changes in environmental conditions, lasted several million years (Erwin 1993, 2006; Retallack 1995) and was accompanied by significant disruptions in the global carbon cycle. This disruption affected marine, terrestrial and atmospheric reservoirs and is indicated by a prominent negative carbon isotope excursion (e.g., Chen et al. 1984; Holser et al. 1989; Krull et al. 2000; Twitchett et al. 2001; Korte et al. 2004a, 2010; Retallack et al. 2005; Algeo et al. 2007; Yin et al. 2007; Heydari et al. 2008). Because of its global extent, the PTB carbon isotope trends are well suited for worldwide stratigraphic correlation (e.g., Baud et al. 1989; Korte \& Kozur 2005a, 2005b, 2010; Gorjan et al. 2008; Grasby \& Beauchamp 2008; Cao et al. 2010; Hermann et al. 2010; Richoz et al. 2010). A number of causes

\footnotetext{
* Corresponding author
} 
have been proposed to account for the negative carbon isotope excursion: (1) enhanced combustion or metamorphism of organic matter in latest Precambrian and Palaeozoic organic-rich sediments by Siberian Trap sills and dykes (e.g., Payne \& Kump 2007; Retallack \& Jahren 2008; Svensen et al. 2009; Korte et al. 2010), (2) a global sea level drop enabling the erosion of ${ }^{13} \mathrm{C}$-depleted organic-rich sediments (e.g., Holser \& Magaritz 1987; Baud et al. 1989), (3) a collapse of oceanic primary productivity (e.g., Magaritz 1989; Visscher et al. 1996), (4) the release of methane from the sea floor, permafrost soils, or coal deposits (e.g., Erwin 1994; Krull \& Retallack 2000; Heydari et al. 2008), or (5) anoxic bottom waters reaching ocean surfaces by rise of the chemocline or oceanic overturn (e.g., Malkowski et al. 1989; Knoll et al. 1996; Kump et al. 2005; Riccardi et al. 2007; Algeo et al. 2008). Not surprisingly, the PTB carbon isotope trend may also have been caused by a combination of several of these factors (e.g., Berner 2002; Sephton et al. 2005; Corsetti et al. 2005; Retallack \& Jahren 2008; Korte et al. 2010).

The negative carbon isotope excursion at the PTB is superimposed by additional positive and negative $\delta^{13} \mathrm{C}$ events (e.g., Korte et al. 2004b, 2004c; Richoz 2006; Algeo et al. 2007, 2008; Kraus et al. 2009; Cao et al. 2010; Korte \& Kozur 2010; Korte et al. 2010; Richoz et al. 2010; Takahashi et al. 2010; Shen et al. 2012a, 2012 b , 2012c). A characteristic, abrupt, $\sim 1 \%$ positive $\delta^{13} \mathrm{C}$ excursion, interrupting the general latest Permian negative trend, occurs just before the low-latitude marine event (mass extinction) horizon (Korte et al. 2004b, 2004c; Richoz 2006; Kraus et al. 2009; Cao et al. 2010; Korte \& Kozur 2010; Korte et al. 2010; Richoz et al. 2010; Takahashi et al. 2010). This positive excursion has recently drawn attention, and authors argued that it might have been caused by enhanced nutrient availability, producing an algal and/or bacterial bloom (Payne \& Kump 2007; Korte et al. 2010; Takahashi et al. 2010), deposition of coaly fly ash from Trap volcanism (Grasby et al. 2011), or enhanced terrestrial influx due to climatic perturbations (Krassilov \& Karasev 2009; Takahashi et al. 2010;
Siegert et al. 2011; see also Wacey et al. 2007). In this publication, we present new organic and inorganic carbon isotope data from two low-latitude marine PTB sections in the European Southern Alps and compare them to literature data from other successions of this region. We examine the extent of a potential terrestrial influence as a function of distance from the palaeocoast, thus constraining nature and extent of the latest-Permian environmental perturbations and its influence on the biotic crisis.

\section{Sections studied}

Samples were collected from the PTB sections at Misci (Bosellini 1964; this locality was also named "Val Badia", Sephton et al. 2002, and "Val Seres"; Cirilli et al. 1998) and San Antonio (Brandner 1988; Oberhänsli et al. 1989), both located in the Dolomites (Southern Alps, Italy; Fig. 1). Misci is situated near Campill/Lungiarü/Longiarù (Bosellini 1964; Cirilli et al. 1998), a few kilometres south-southwest of St. Martin in Thurn in the Val Badia (South Tyrol). The section is exposed about $600 \mathrm{~m}$ west-northwest of the Misci settlement, north of the Rio Seres (see also Cirilli et al. 1998; Sephton et al. 2002). The studied profile $\left(46^{\circ} 38^{\prime} 23^{\prime \prime} \mathrm{N} ; 11^{\circ} 50^{\prime} 35^{\prime \prime} \mathrm{E}\right)$ comprises the upper part of the Bellerophon Formation (the designation "Formazione a Bellerophon" was accepted by the APAT-CNR-Commissione Italiana di Stratigrafia) and the lower part of the Werfen Formation, the latter consisting of the Tesero Oolite Horizon (TOH) (oolitic grainstones) and the lower Mazzin Member (Fig. 2). The strata were deposited about $40 \mathrm{~km}$ east of palaeocoastline (Fig. 1; see Brandner 1988).

The San Antonio section is located along a road cut on the road from Auronzo di Cadore to San Antonio (Fig. 1; see Brandner 1988). Here, the Bellerophon Formation is directly succeeded by the Mazzin Member; the TOH is absent (Fig. 3). This location is about $90 \mathrm{~km}$ east of the palaeocoastline (Fig. 1; Brandner 1988). The base of the section (Bellerophon Formation) is composed of thick-bedded wackestone and mudstone

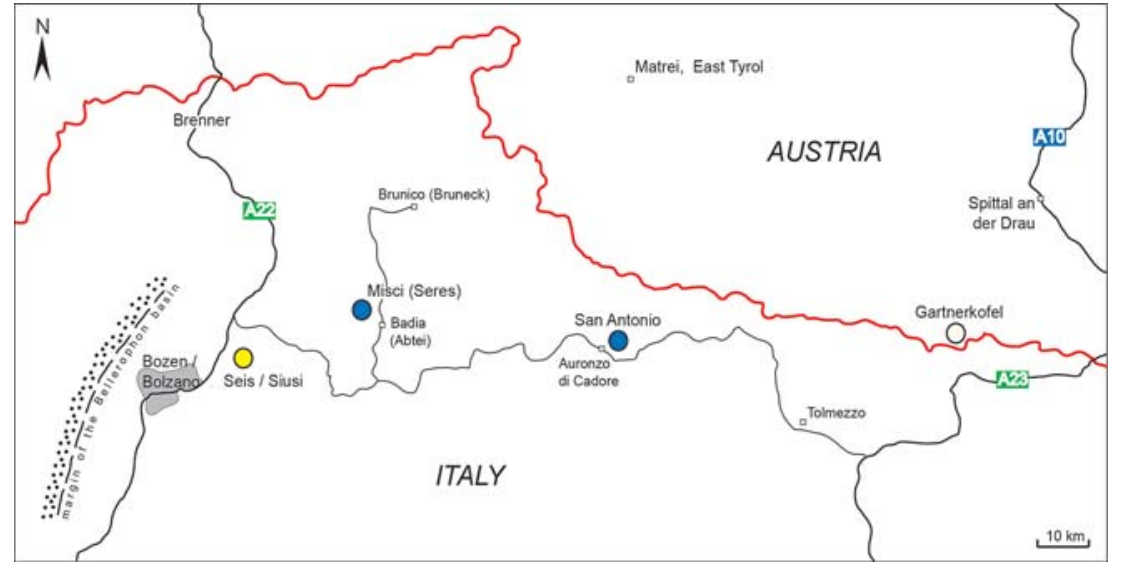

Figure 1. Geographical sketch map of the Southern Alps showing sample localities (blue) and other sections discussed in text (yellow). The palaeocoastline of the Bellerophon basin was situated about $10 \mathrm{~km}$ west of Bozen/ Bolzano. Figure modified after Brandner (1988) and Kraus et al. (2009). 


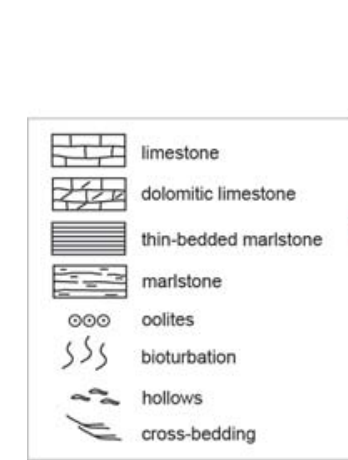

A
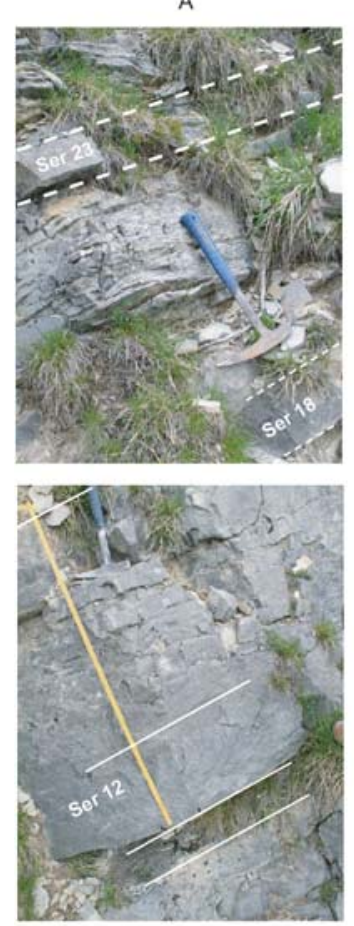

B
Misci (Seres)

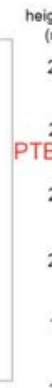

height sys- litho-

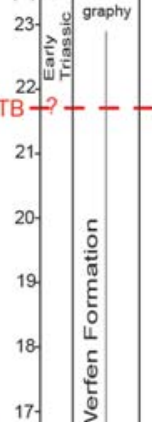

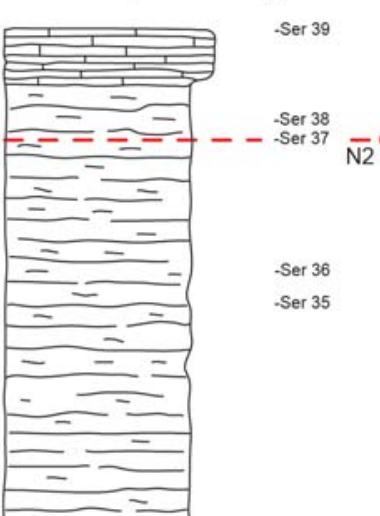
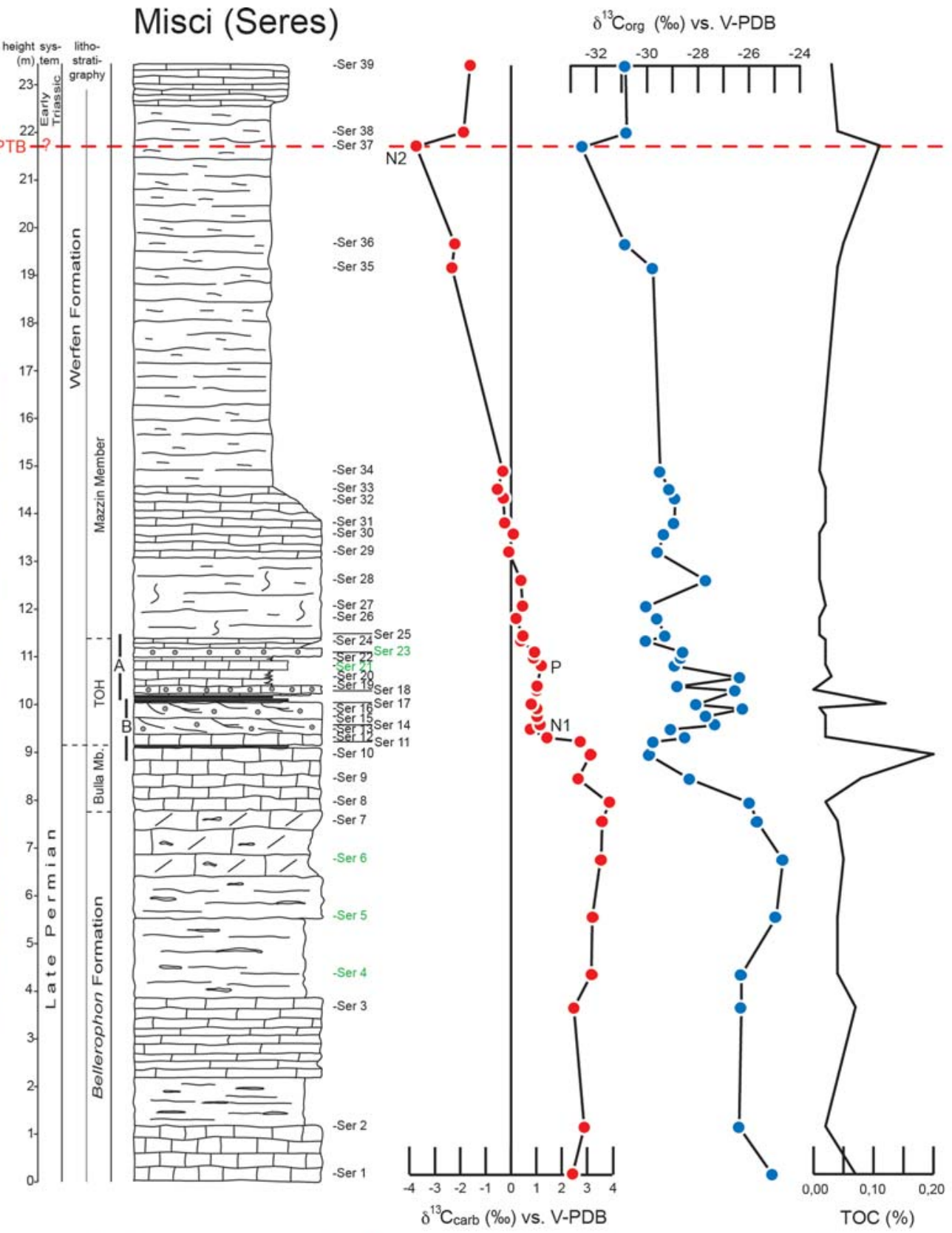

Ser-23
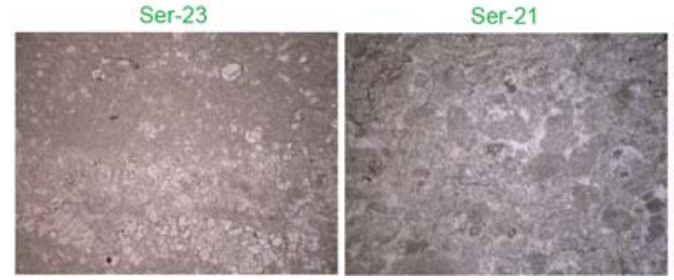

Ser-6

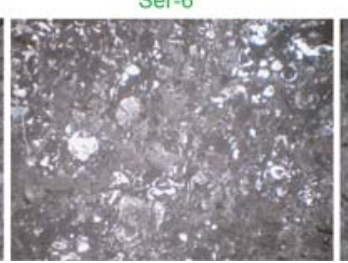

Ser-5

Ser- 4

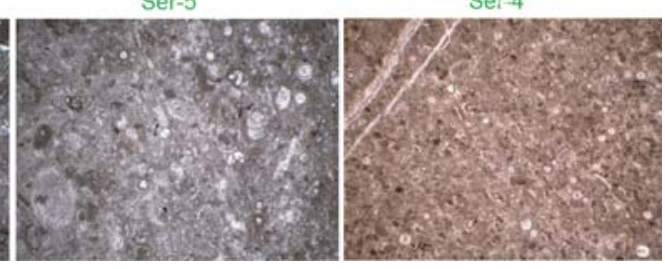

Figure 2. Stratigraphy, lithology, carbon isotope values, and TOC concentrations of the Misci section. Outcrop photographs illustrate outcrop conditions, thin sections of selected samples show characteristic petrographic composition. A negative (N1) and a positive (P) $\delta^{13} \mathrm{C}$ excursion modify the general negative $\delta^{13} \mathrm{C}$ trend which leads up to the PTB, located near the minimum N2; cf. Korte \& Kozur (2010).

alternating with beds of thin platy marls. The Bulla Member, starting at about $1 \mathrm{~m}$ of the measured stratigraphic section, consists of dolomitic mudstone, interbedded with packstone and marl. The Mazzin Member consists of mudstone interbedded with thin-bedded marl (Fig. 3). The sedimentation rate at the San Antonio suc- cession was lower than at Misci, probably because of its more distal location (Brandner 1988).

Sedimentological observations and the palaeogeographical reconstruction indicate shallower water depths towards the west (Fig. 1; see also Brandner 1988; Brandner et al. 2009). 


\section{Methods}

Thin sections of carbonates from the Bellerophon Formation and the $\mathrm{TOH}$ at Misci and from the Bellerophon Formation and the Mazzin Member at San Antonio (Figs 2, 3) aided in the identification of rock types and microfacies (see below).

About $1.5 \mathrm{~g}$ of powder was drilled from 39 and 33 fresh surfaces of cleaned marly or micritic carbonate rock samples from Misci and San Antonio, respectively. Drilling was restricted to 5 seconds to avoid unwanted heating. Small portions $(100-400 \mu \mathrm{g})$ of the pro- duced powders were filled into $10 \mathrm{ml}$ vials and sealed with septum caps. The vials were then flushed with helium for $6 \mathrm{~min}$; subsequently $\mathrm{H}_{3} \mathrm{PO}_{4}$ was added. Generated $\mathrm{CO}_{2}$ was analysed for $\delta^{13} \mathrm{C}_{\text {carb }}$ and $\delta^{18} \mathrm{O}$ on a Thermo Finnigan Gasbench II linked online to a Thermo Finnigan Delta V mass spectrometer at the Museum für Naturkunde Berlin. The reproducibility of replicated standards was better than $0.1 \%$ (one standard deviation) for both $\delta^{13} \mathrm{C}$ and $\delta^{18} \mathrm{O}$. Carbon- (and oxygen)-isotope values were calibrated against V-PDB and are reported in conventional delta notation (Tab. 1). The remaining sample powders were de-carbonated with $2 \mathrm{M}$ hydrochloric acid following Siegert et al. (2011). About $40 \mathrm{mg}$ and $50 \mathrm{mg}$ of the treated and dried sam-

Table 1. Stratigraphic sample location, carbon isotope and TOC values at the Misci section.

\begin{tabular}{|c|c|c|c|c|c|}
\hline Sample & height (m) & $\begin{array}{l}\delta^{13} C_{c a r b} \\
{[\% \text { ] vs. VPDB }}\end{array}$ & $\begin{array}{l}\delta^{13} C_{\text {org }} \\
{[\% \text { ] vs. VPDB }}\end{array}$ & $\begin{array}{l}\text { TOC }[\%] \\
\text { (decarbonised sample) }\end{array}$ & $\begin{array}{l}\text { TOC [\%] } \\
\text { (sample) }\end{array}$ \\
\hline Ser 1 & 0.15 & 2.42 & -25.07 & 1.02 & 0.07 \\
\hline Ser 2 & 1.15 & 2.89 & -26.39 & 1.64 & 0.02 \\
\hline Ser 3 & 3.65 & 2.48 & -26.30 & 2.01 & 0.07 \\
\hline Ser 4 & 4.35 & 3.17 & -26.30 & 2.80 & 0.04 \\
\hline Ser 5 & 5.55 & 3.21 & -24.93 & 1.16 & 0.04 \\
\hline Ser 6 & 6.75 & 3.53 & -24.67 & 1.24 & 0.05 \\
\hline Ser 7 & 7.55 & 3.57 & -25.67 & 1.40 & 0.04 \\
\hline Ser 8 & 7.95 & 3.86 & -25.96 & 6.88 & 0.02 \\
\hline Ser 9 & 8.45 & 2.64 & -28.31 & 9.47 & 0.08 \\
\hline Ser 10 & 8.95 & 3.13 & -29.91 & 24.75 & 0.20 \\
\hline Ser 11 & 9.22 & 2.73 & -29.75 & 10.45 & 0.06 \\
\hline Ser 12 & 9.3 & 1.42 & -28.47 & 3.81 & 0.02 \\
\hline Ser 13 & 9.48 & 0.74 & -29.07 & 0.98 & 0.02 \\
\hline Ser 14 & 9.57 & 1.16 & -27.30 & 0.72 & 0.02 \\
\hline Ser 15 & 9.75 & 1.02 & -27.68 & 0.85 & 0.02 \\
\hline Ser 16 & 9.91 & 1.02 & -26.23 & 0.47 & 0.01 \\
\hline Ser 17 & 10 & 0.79 & -28.07 & 16.14 & 0.12 \\
\hline Ser 18 & 10.29 & 1.01 & -26.51 & 0.97 & 0.00 \\
\hline Ser 19 & 10.38 & 1.03 & -28.80 & 0.62 & 0.01 \\
\hline Ser 20 & 10.565 & & -26.34 & 0.33 & 0.03 \\
\hline Ser 21 & 10.813 & 1.19 & -28.91 & 0.55 & 0.02 \\
\hline Ser 22 & 10.975 & 0.88 & -28.66 & 0.37 & 0.02 \\
\hline Ser 23 & 11.095 & 0.94 & -28.57 & 0.36 & 0.02 \\
\hline Ser 24 & 11.335 & 0.37 & -30.05 & 0.52 & 0.02 \\
\hline Ser 25 & 11.435 & 0.47 & -29.27 & 0.41 & 0.01 \\
\hline Ser 26 & 11.8 & 0.20 & -29.60 & 0.48 & 0.01 \\
\hline Ser 27 & 12.055 & 0.46 & -30.03 & 0.47 & 0.02 \\
\hline Ser 28 & 12.6 & 0.39 & -27.67 & 0.67 & 0.01 \\
\hline Ser 29 & 13.195 & -0.09 & -29.58 & 0.40 & 0.01 \\
\hline Ser 30 & 13.57 & 0.09 & -29.33 & 0.49 & 0.01 \\
\hline Ser 31 & 13.8 & -0.25 & -28.93 & 1.25 & 0.02 \\
\hline Ser 32 & 14.32 & -0.30 & -28.89 & 0.42 & 0.02 \\
\hline Ser 33 & 14.51 & -0.54 & -29.12 & 0.42 & 0.02 \\
\hline Ser 34 & 14.88 & -0.32 & -29.48 & 0.17 & 0.01 \\
\hline Ser 35 & 19.15 & -2.33 & -29.76 & 0.22 & 0.04 \\
\hline Ser 36 & 19.65 & -2.22 & -30.85 & 0.25 & 0.05 \\
\hline Ser 37 & 21.69 & -3.74 & -32.56 & 0.51 & 0.11 \\
\hline Ser 38 & 21.99 & -1.87 & -30.79 & 0.35 & 0.04 \\
\hline Ser 39 & 23.39 & -1.61 & -30.84 & 0.39 & 0.03 \\
\hline
\end{tabular}



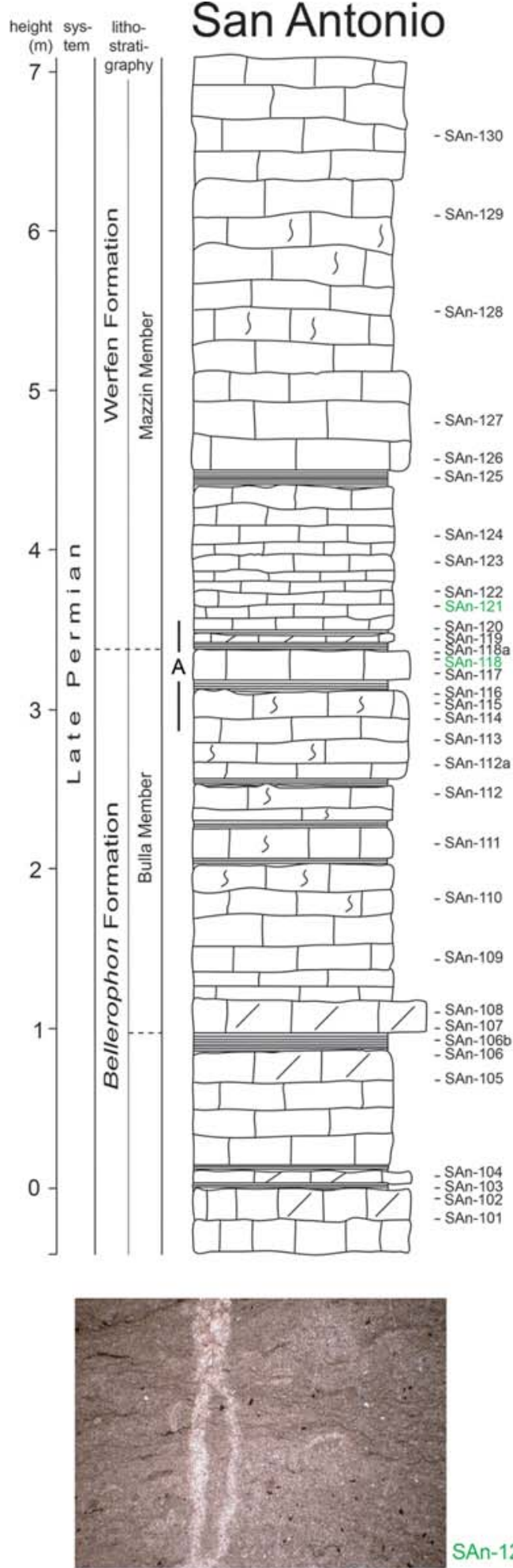

SAn-121

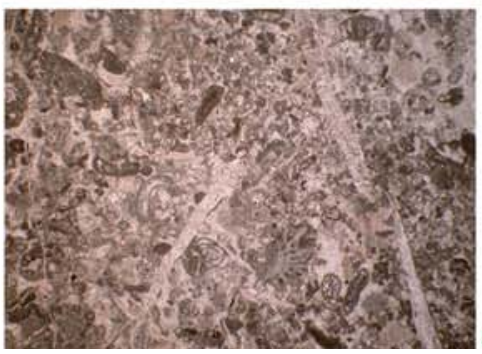

SAn-118

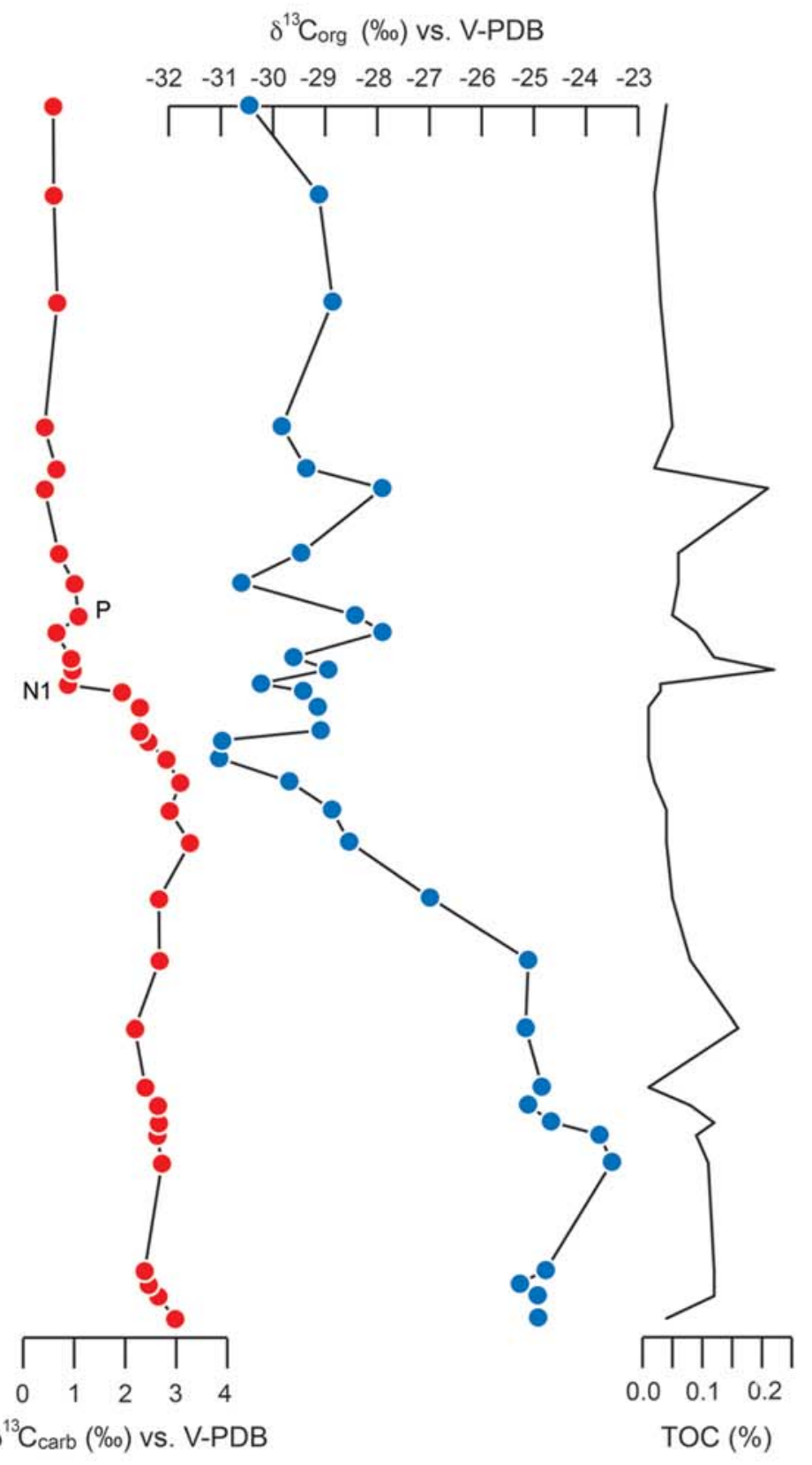

A

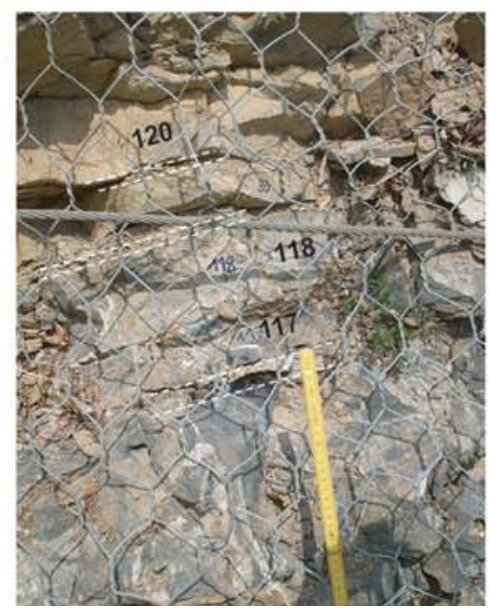

Figure 3. Stratigraphy, lithology, carbon isotope values and TOC concentrations of San Antonio section. Outcrop photographs illustrate outcrop conditions, thin sections of selected samples show characteristic petrographic composition. (See Figure 2 for N1 and P). 
ples from Misci and San Antonio, respectively, were subsequently packed into tin capsules. $\delta^{13} \mathrm{C}_{\text {org }}$ and total organic carbon (TOC) was then measured using a THERMO/Finnigan MAT V isotope ratio mass spectrometer, coupled to a THERMO Flash EA 1112 elemental analyzer via a THERMO/Finnigan Conflo III-interface at the stable isotope laboratory of the Museum für Naturkunde Berlin (Tab. 1). The organic carbon isotope ratios were expressed in the standard \%o notation relative to VPDB. The standard deviation for repeated measurements of lab standard material (peptone) was better than $0.15 \%$ $($ error $= \pm 0.2)$.

\section{Results}

Field and thin section observations demonstrate that the fine- to coarse-grained packstones to grainstones are generally strongly bioturbated and of variable framework composition. They likely reflect the thorough mixing of products by several carbonate grain "factories" and suggest water depths of several tens of metres. The lower $9 \mathrm{~m}$ of the Misci section consist of partly marly carbonates of the Bellerophon Formation. Cavernous carbonates, presumably produced by secondary dissolution of evaporitic minerals, occur between 1-2 and 4-8 m (Fig. 2). Spherical structures interpreted as ooids or calcispheres occur at $4 \mathrm{~m}$ (sample Ser-4); they are absent in samples Ser-5, Ser-6, Ser-21 and Ser-23. No ooids were identified in the outcrop nor in thin sections from San Antonio (Fig. 3); the dominant rock types there are foraminifer-mollusk biosparite (SAn-118) and fossil-free micritic mudstone (SAn-121). $\delta^{13} \mathrm{C}_{\text {carb }}$ values from the PTB section at Misci (Fig. 2) vary from $+3.9 \%$ in the upper Bellerophon Formation to $+3.7 \%$ in the Mazzin Member. The

Table 2: Sample location, carbon isotope and TOC values at the San Antonio section.

\begin{tabular}{|c|c|c|c|c|c|}
\hline sample & $\begin{array}{l}\text { height } \\
\text { (m) }\end{array}$ & $\begin{array}{l}\delta^{13} C_{\text {carb }} \\
{[\% \circ] \text { vs. VPDB }}\end{array}$ & $\begin{array}{l}\delta^{13} C_{\text {org }} \\
{[\% \text { ] vs. VPDB }}\end{array}$ & $\begin{array}{l}\text { TOC }[\%] \\
\text { (decarbonised sample) }\end{array}$ & $\begin{array}{l}\text { TOC [\%] } \\
\text { (sample) }\end{array}$ \\
\hline SAn 101 & -0.19 & 2.98 & -24.90 & 0.89 & 0.04 \\
\hline SAn 102 & -0.07 & 2.65 & -24.92 & 0.64 & 0.12 \\
\hline SAn 103 & 0.00 & 2.46 & -25.27 & 0.74 & 0.12 \\
\hline SAn 104 & 0.07 & 2.38 & -24.76 & 0.65 & 0.12 \\
\hline SAn 105 & 0.68 & 2.72 & -23.50 & 0.78 & 0.11 \\
\hline SAn 106 & 0.83 & 2.63 & -23.74 & 0.61 & 0.09 \\
\hline SAn 106b & 0.90 & 2.66 & -24.66 & 0.61 & 0.12 \\
\hline SAn 107 & 1.00 & 2.64 & -25.11 & 0.55 & 0.08 \\
\hline SAn 108 & 1.10 & 2.40 & -24.84 & 1.22 & 0.01 \\
\hline SAn 109 & 1.43 & 2.19 & -25.15 & 0.76 & 0.16 \\
\hline SAn 110 & 1.81 & 2.67 & -25.10 & 1.03 & 0.08 \\
\hline SAn 111 & 2.16 & 2.66 & -26.99 & 1.35 & 0.05 \\
\hline SAn 112 & 2.47 & 3.27 & -28.54 & 2.65 & 0.04 \\
\hline SAn $112 a$ & 2.65 & 2.87 & -28.87 & 3.26 & 0.04 \\
\hline SAn 113 & 2.81 & 3.08 & -29.68 & 5.74 & 0.02 \\
\hline SAn 114 & 2.94 & 2.80 & -31.04 & 12.06 & 0.01 \\
\hline SAn 115 & 3.04 & 2.45 & -30.97 & 5.51 & 0.01 \\
\hline SAn 116 & 3.09 & 2.28 & -29.07 & 5.92 & 0.01 \\
\hline SAn 117 & 3.23 & 2.29 & -29.14 & 1.71 & 0.01 \\
\hline SAn 118 & 3.31 & 1.94 & -29.41 & 0.85 & 0.03 \\
\hline SAn 118a & 3.36 & 0.87 & -30.25 & 0.78 & 0.03 \\
\hline SAn 119 & 3.43 & 0.97 & -28.92 & 0.13 & 0.22 \\
\hline SAn 120 & 3.50 & 0.94 & -29.60 & 0.19 & 0.12 \\
\hline SAn 121 & 3.64 & 0.65 & -27.89 & 0.17 & 0.09 \\
\hline SAn 122 & 3.74 & 1.09 & -28.43 & 0.19 & 0.05 \\
\hline SAn 123 & 3.92 & 1.01 & -30.62 & 0.31 & 0.06 \\
\hline SAn 124 & 4.09 & 0.70 & -29.45 & 0.28 & 0.06 \\
\hline SAn 125 & 4.45 & 0.42 & -27.90 & 0.12 & 0.21 \\
\hline SAn 126 & 4.56 & 0.65 & -29.36 & 0.37 & 0.02 \\
\hline SAn 127 & 4.80 & 0.42 & -29.83 & 0.47 & 0.05 \\
\hline SAn 128 & 5.50 & 0.67 & -28.85 & 0.37 & 0.03 \\
\hline SAn 129 & 6.10 & 0.60 & -29.12 & 0.46 & 0.02 \\
\hline SAn 130 & 6.60 & 0.59 & -30.45 & 0.52 & 0.04 \\
\hline
\end{tabular}


variability in the upper Bellerophon Formation is relatively low $(+2.4$ to $+3.9 \%)$; this is also characteristic for other time-equivalent South Alpine and Tethyan sections (e.g., Baud et al. 1989; Holser et al. 1989; Korte \& Kozur 2010). The values decrease sharply from $+2.7 \%$ (Ser-11) to $+0.7 \%$ o (Ser-13) in the lower TOH (Fig. 2: N1) and then remain relatively constant at about $1 \%$. A positive excursion in the general decreasing trend starts in the middle part of the $\mathrm{TOH}$ (Ser-17) and ends near its top (Ser-26) (Fig. 2: P). Subsequently, the carbonate carbon isotope values decrease gradually from $+0.5 \%$ (Ser-27) and reach a minimum of $-3.7 \%$ in the Mazzin Member (Ser-37). The $\delta^{13} \mathrm{C}$ values of Ser-38 and Ser-39, in the highest part of the section, are between -1.5 and $-2.0 \%$.

The $\delta^{13} \mathrm{C}_{\text {org }}$ values from Misci vary between -24.7 and $-32.6 \%$. The variability in the upper Bellerophon Formation is low and ranges between -26.3 and $-24.6 \%$. A decreasing trend starts about $1 \mathrm{~m}$ below the TOH within the Bulla Member and reaches $29.9 \%$ at its top. The organic-carbon isotope values increase significantly from Ser-11 - exactly where carbonate $\delta^{13} \mathrm{C}$ values start to decrease (Fig. 2; Tab. 1) - and create a positive excursion until the top of the TOH (Ser-24). Higher up, the $\delta^{13} C_{\text {org }}$ values remain - with some exceptions - relatively constant. They show, as does $\delta^{13} C_{\text {carb}}$, a minimum in sample Ser-37 of $32.6 \%$.

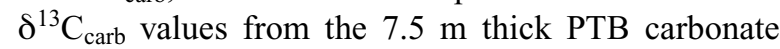
sequence at San Antonio (Fig. 3) vary from + 3.3\%o (Bulla Member) to $+0.4 \%$ (Mazzin Member). This range is distinctly smaller than at Misci (8\%), confirming earlier observations of higher carbonate carbon isotope variability for shallower sections (and high latitudes) (Krull et al. 2000; Twitchett et al. 2001; Korte et al. 2010). At San Antonio, variability in the upper Bellerophon Formation is between +2.2 and $+3.3 \%$. Values begin to decrease at sample SAn-114 and fall gradually from about +2.3 to about $+0.9 \%$ until reaching the boundary between the Bellerophon Formation and the Werfen Formation (Figs 3, 4: N1), which is similar to the Misci record. A small positive excursion (Figs 3 and 4: P) of nearly $0.7 \%$ occurs between sample SAn-121 and SAn-125. The $\delta^{13} C_{\text {carb }}$ values remain at about $+0.6 \%$ up to the top of the section.

$\delta^{13} \mathrm{C}_{\mathrm{org}}$ values from the San Antonio section vary similar to those from Misci - by $\sim 7.5 \%$. They decrease - in contrast to the $\delta^{13} \mathrm{C}_{\text {carb }}$ - already in the lower Bulla Member (SAn-110), about $1.5 \mathrm{~m}$ below the boundary between the Bellerophon and the Werfen Formations. This decline is gradual and ranges from -24.6 to $-31.0 \%$. Subsequently and in the upper Bulla Member, the organic carbon isotopes show a two-peaked positive excursion with maxima of $-27.9 \%$ in samples SAn121 and SAn-125. Stratigraphically higher, the $\delta^{13} C_{\text {org }}$ values vary between -30.4 to $-29.4 \%$.

TOC concentrations of organic matter of the Misci and San Antonio samples are low, averaging 0.04\% and $0.07 \%$, respectively. These low concentrations are typical for platform carbonates. The $\delta^{13} C_{\text {org }}$ values must thus be interpreted with caution where they fall below $0.02 \%$ (Magaritz et al. 1992). Slightly higher TOC values of up to $0.2 \%$ are present in the thinbedded marl.

\section{Discussion}

Carbon isotope fluctuations, if global in nature, are recorded across a broad range of marine and continental sediments such as shallow-water and pelagic carbonates, organic-rich shales, palaeosols and lacustrine deposits. Thus, maxima and minima in isotope variations are useful tools for intercontinental stratigraphic correlations and have been applied to the prominent negative carbon isotope excursion at the PTB (e.g., Baud et al. 1989; Korte \& Kozur 2005a, 2010; Gorjan et al. 2008; Grasby \& Beauchamp 2008; Cao et al. 2010; Hermann et al. 2010; Korte et al. 2010; Richoz et al. 2010). Recently, Korte \& Kozur (2010) have suggested a general carbonate carbon isotope trend for the PTB, calibrated by biostratigraphically well-defined sections. Their suggested trend, used here as a baseline in the following discussion, shows four characteristics: (1) A gradual $4 \%$ to $7 \%$ decline, beginning in the Clarkina bachmanni Zone, and lasting about 500,000 years; (2) A short-term, about $1 \%$ positive excursion, starting just below the low-latitude marine event horizon and interrupting the general negative trend ( $\mathrm{P}$ in Fig. 4); (3) A first minimum (N2 in Figure 4) situated close to the PTB at the first-appearance-datum (FAD) of Hindeodus parvus (Kozur \& Pjatakova, 1976); (4) A second, occasionally two-peaked minimum in the lower and middle Isarcicella isarcica Zone which occurs after a slight increase.

We include in the following discussion published carbonate and organic carbon isotope data for the PTB succession in Seis/Siusi (Kraus et al. 2009; Siegert et al. 2011; Figs 1, 4) for comparison (see also Horacek et al. 2010). In general, it is difficult to biostratigraphically define precisely the PTB in the Southern Alps because the sediments are rare in conodonts. No conodont data exist at Seis, Misci, and San Antonio; thus, other stratigraphic tools must be applied. The conodont Hindeodus, however, is reported from the Southern Alps at the Reppwand (Gartnerkofel core) and Pufels/Bula/Bulla (Schönlaub 1991; Perri 1991; Farabegoli \& Perri 1998), allowing the definition of the PTB and its correlation to the carbon isotope curve (see Korte \& Kozur 2010; Korte et al. 2010). This definition has been used to suggest the possible location of the stratigraphic horizon of the PTB at Seis (Kraus et al. 2009; Siegert et al. 2011) which can be applied for Misci, too. Following this line of reasoning, the biostratigraphic (conodontdefined) PTB in this section is drawn at the carbonate carbon isotope minimum (cf. Korte \& Kozur 2010), about $11.5 \mathrm{~m}$ above the base of the TOH (Fig. 2: N2). This location is nearly identical to its location in the 


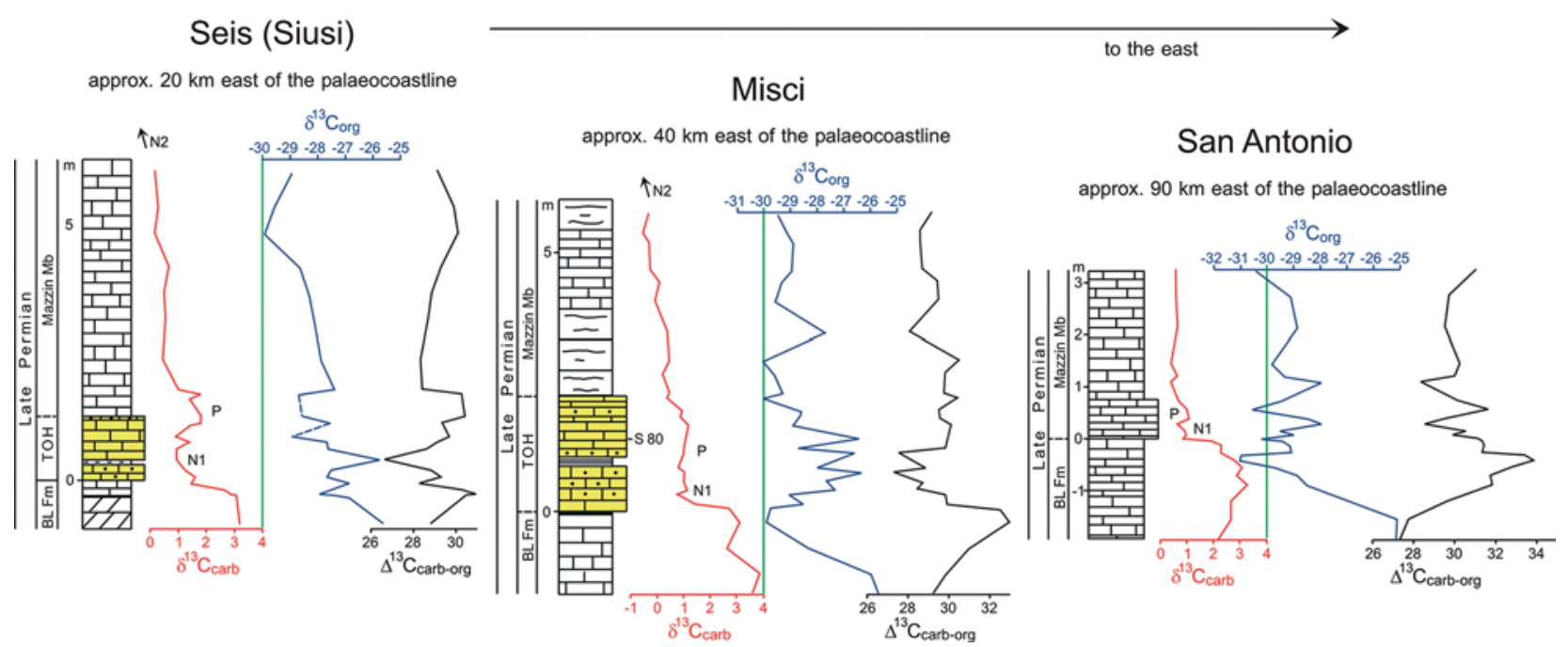

Figure 4. Time-stratigraphic correlation of the carbonate and organic carbon isotope records and the $\Delta{ }^{13} \mathrm{C}_{\text {carb-org }}$ curve (all \%o vs VPDB) of the Seis (Kraus et al. 2009; Siegert et al. 2011), Misci (this study), and San Antonio (this study) sections. Note different vertical scales in the three sections. Correlation is based on the base of the $\delta^{13} \mathrm{C}_{\text {carb }}$ positive peak and the low-latitude marine mass extinction event (= event horizon EH) (see Korte \& Kozur 2010; Kozur \& Weems 2010). This event is - according to Cirilli et al. (1998) - situated slightly above their sample S80 at Misci section (chronostratigraphic height in the present study was corrected by $0.38 \mathrm{~m}$ because of slight variations in thicknesses of the beds compared to Cirilli et al. 1998). (See Figure 2 for N1, N2 and P).

$\delta^{13} \mathrm{C}_{\text {carb }}$ isotope curve at the adjacent Pufels section (Korte et al. 2010), where the PTB is interpreted to occur about 12 meters above the base of the TOH. This suggested correlation is also supported by the proximity of the Pufels and Misci sections, suggesting similar sedimentation rates in both sections. A distinct $\delta^{13} \mathrm{C}$ minimum is not present in the carbonate carbon isotope curve above the base of the Mazzin Member in San Antonio (Fig. 3), suggesting that the biostratigraphic (conodont) PTB might not be present in the investigated part of this section, and may occur upsection if the succession is complete.

The gradual decreasing carbonate carbon isotope trend in all three sections is interrupted by a (slightly pronounced) 0.5 to $1 \%$ short-term positive excursion (Figs 2, 3) which occurs in Misci between Ser-17 and Ser-26 and in San Antonio between SAn-121 and SAn125 (see also Kraus et al. 2009, for Seis). These shortterm positive $\delta^{13} \mathrm{C}$ shifts represent a chemostratigraphic marker which occurs somewhat below the low-latitude marine event horizon (cf. Kraus et al. 2009; Korte \& Kozur 2010; Richoz et al. 2010). Palynological data from Misci (Cirilli et al. 1998) indicate that the event horizon (EH) occurs slightly above their sample S80 (indicated in Figure 4). Our field observations, however, suggest that the EH is located at sample Ser-17. In the San Antonio section (see also Brandner 1988), the EH is located at the base of the thin-bedded marlstone (above SAn 118a), indicated by a change from mollusc-foram biosparite to micritic limestone (mudstone). Because of the strong shifts in $\delta^{13} C_{\text {carb }}$ and TOC (Fig. 2) at this position, a short hiatus cannot be excluded there. Further details regarding stratigraphic correlation at the PTB in the Southern Alps are described by Assereto et al. (1973), Mostler (1982), Noé
(1987), Wignall \& Hallam (1992), Cirilli et al. (1998), Scholger et al. (2000), Korte \& Kozur (2005a, 2010), Farabegoli et al. (2007), Horacek et al. (2007, 2010), Posenato (2008), Brandner et al. (2009), Kraus et al. (2009) and Korte et al. (2010).

The organic carbon isotope values in all three sections (Fig. 4) deviate from the carbonate $\delta^{13} \mathrm{C}$ trend (Compare also the $\Delta^{13} \mathrm{C}_{\text {carb-org }}$ curve of Fig. 4 . The variability in $\delta^{13} \mathrm{C}_{\text {org }}$ in that figure is, however, twice that of $\delta^{13} \mathrm{C}_{\text {carb. }}$. Thus, its $\Delta{ }^{13} \mathrm{C}_{\text {carb-org }}$ curve mainly reflects the characteristics of the $\delta^{13} \mathrm{C}_{\text {org }}$ curve) by a temporary distinctive increase of $\delta^{13} C_{\text {org }}$ while $\delta^{13} C_{\text {carb }}$ values remain constant or decreasing around the transition from the Bellerophon Formation to the Werfen Formation (near the $\mathrm{TOH}$ ). Carbon isotope fluctuations are generally reflected in marine carbonates and in marine phytoplankton because their carbon source, the dissolved inorganic carbon (DIC) reservoir, is the same. The absolute values of the organic matter, however, are distinctly lighter compared to those of the carbonates because plants discriminate strongly against ${ }^{13} \mathrm{C}$. Deviating organic and inorganic $\delta^{13} \mathrm{C}$ trends can be explained by ocean anoxia which was widespread in the latest Permian and evidenced by several successions in the Tethys and Panthalassa (e.g., Wignall \& Hallam 1992; Wignall \& Twitchett 1996; Isozaki 1997; Twitchett et al. 2001; Nielsen \& Shen 2004; Grice et al. 2005; Kump et al. 2005; Hays et al. 2007; Algeo et al. 2008, 2012) and may have reached very shallow waters (e.g., Kump et al. 2005; Riccardi et al. 2007). Anoxia will affect the sedimentary organic $\delta^{13} \mathrm{C}$ as follows: Under anoxic and reducing conditions in the photic zone, green sulphur bacteria (Chlorobiaceae) can thrive by using $\mathrm{H}_{2} \mathrm{~S}$ and $\mathrm{CO}_{2}$ for anaerobic photosynthesis. This process will not discriminate as much against ${ }^{12} \mathrm{C}$ as 
photosynthesis of marine phytoplankton in an oxygenated photic zone (Sirevag et al. 1977) and has been suggested as a cause that $\delta^{13} \mathrm{C}_{\text {carb }}$ and $\delta^{13} \mathrm{C}_{\text {org }}$ trends at the PTB deviate temporarily from each other (Riccardi et al. 2007). The pronounced increase of the organic carbon isotope values around the TOH in the Southern Alps, however, occurs at the Misci and San Antonio section already in the Bulla Member (Figs 2, 3) where the fully developed benthos in this member indicates continuously well oxygenated water: thus, this hypothesis is unlikely.

Deviating $\delta^{13} \mathrm{C}_{\text {org }}$ trends can also been caused by varying proportions of marine organic matter vs. land plant material. In general, terrestrial plants can (also) reflect carbon isotopes fluctuations because carbon as $\mathrm{CO}_{2}$ is continuously exchanged between ocean and atmosphere. Although $\delta^{13} \mathrm{C}$ in plants is dominated by taxonomic, environmental, and diagenetic factors (e.g., Gröcke 1998; Poole et al. 2006) rather than by the isotopic composition of atmospheric $\mathrm{CO}_{2}$ alone, studies of continental organic matter have shown that stratigraphic signatures are nevertheless recorded, indicating that the atmospheric signal dominated over local factors (e.g., Hasegawa et al. 1997; Gröcke et al. 1999; Arens et al. 2000; Hesselbo et al. 2007; Nunn et al. 2010; Belcher et al. 2010; Korte \& Hesselbo 2011; Dal Corso et al. 2011). However, Permian wood shows heavier $\delta^{13} \mathrm{C}$ values than coeval marine-sourced organic matter (Faure et al. 1995; Foster et al. 1997; Krull 1999; Korte et al. 2001; Ward et al. 2005; Hermann et al. 2010) and thus affects the bulk $\delta^{13} \mathrm{C}_{\text {org }}$ value of marine sediments because the TOC in these deposits can be of marine or terrigenous origin (Whiticar 1996). A change in the percentage of the marine-to-terrigenous ratio of $\delta^{13} \mathrm{C}_{\text {org }}$ was probably responsible for the negative carbon-isotope excursion in marine successions in Australia where a source of predominant woody tissues $\left(\delta^{13} \mathrm{C}=\right.$ $-24 \%$ ) changed to one dominated by acritarchs $\left(\delta^{13} \mathrm{C}=-30 \%\right.$ ) (Gorter et al. 1995; Foster et al. 1997; see also Thomas et al. 2004). In contrast, heavier $\delta^{13} \mathrm{C}$ values would be produced by temporarily higher influx of land plant material in latest Permian seas, suggested for the southern near-shore PTB successions of the Southern Alps (Siegert et al. 2011). An influx of land plant material in western Tethys PTB sections at that time is also supported by palynofacies analyses (spores, pollen, fungal remains) and isotope ratios of n-alkanes $\left(\delta^{13} \mathrm{C}_{\text {alk }}\right)$ reported at Misci (Cirilli et al. 1998; Sephton et al. 2002; Watson et al. 2005), and by n-alkane $\delta^{13} \mathrm{C}$ at Idrijca Valley (Slovenia), Rizvanuša and Brezimenjača (both Croatia) (Schwab \& Spangenberg 2004; Fio et al. 2010). Additional geochemical data characterising the organic matter in Seis and San Antonio, however, would likely shed more light on this issue.

The latest-Permian sediments at the studied sections represent increasing W-to-E (Seis, Misci, San Antonio) distances from the palaeocoastline (Figs 1, 4). If the influx of land plant material had indeed impacted the bulk $\delta^{13} \mathrm{C}_{\text {org }}$, the organic carbon isotope values should be lighter in the distal sections because the proportion of land plant material would be reduced. This hypothesis can be evaluated by comparing data from the three sections: the lightest $\delta^{13} \mathrm{C}_{\text {org }}$ values prior to the positive excursions (starting somewhat below the $\mathrm{TOH}$ ) are $28.5 \%$, $-30 \%$ and $-31.5 \%$ at Seis, Misci and San Antonio, respectively (Fig. 4). Similarly, from W to E, the heaviest values of the positive excursions are $-25.7 \%$, $-26.5 \%$ and $-27.8 \%$. In addition, the lightest $\delta^{13} \mathrm{C}_{\text {org }}$ values are $-29 \%,-30 \%$, and $-31 \%$ somewhat above the $\mathrm{TOH}$, and $-29.0 \%$, $-29.5 \%$, and $-30.5 \%$ in highest part of the investigated sections, each series cited in the same order as above (Fig. 4); the influence of the heavier isotope is more pronounced during and after the positive excursion. The data trends show clearly that the marine sediments at the investigated sections were consistently less affected by heavier carbon isotopes with increasing distance from the coastline, a trend which favours a diminishing contribution of land plant material. Because all three sections show the smallest difference in $\delta^{13} \mathrm{C}$ in the positive $\delta^{13} \mathrm{C}_{\text {org }}$ excursion, the data thus support the suggestion by Siegert et al. (2011) that the positive $\delta^{13} C_{\text {org }}$ excursion in the Southern Alps near the mass extinction event was mainly produced by a short-lived enhanced influx of land plant material. However, the postulated land plant influx was most probably not the main cause for the positive carbonate carbon isotope excursion at the low-latitude marine event horizon (cf. Korte \& Kozur 2010) because this $\delta^{13} C_{\text {carb }}$ excursion occurs much later.

What was the reason for such an enhanced influx of land plant material? Enhanced freshwater influx into the latest Permian oceans was the logical conveying mechanism and is documented by changes from dominating bisaccate pollen to trilete cavate spores (Visscher 1971; Balme 1979; Foster 1982; Utting 1994; Kozur 1998a, 1998b; Naugolnykh \& Zavialova 2004; Krassilov \& Karasev 2009), by increasing precipitation in arid zones such as in the Germanic Basin (where hypersaline sabkha deposits are overlain by fresh-water lake and fluvial sediments), and/or by and by coarser sediments and wider channels near the PTB in eastern Australia (Michaelsen 2002), South Africa (Ward et al. 2000) and Russia (Newell et al. 1999), all indicating an increase of stream water power. Intensive rains which began close to the low-latitude marine event horizon (Kozur 1998a, 1998b; Krassilov \& Karasev 2009; Korte \& Kozur 2011) were linked to enhanced atmospheric aerosol outgassing from Siberian Trap volcanism by Kozur (1998a, 1998b) and Korte \& Kozur (2011). Pulses of increased freshwater run-off may also have formed fresh-water lenses and suppressed water column overturn near the coastline, facilitating anoxia and aiding the growth of green-sulphur bacteria comparatively heavy in $\delta^{13} C_{\text {org. }}$. Alternatively or additionally, the stripping of large volume of dead terrestrial plant cover as a consequence of environmental disruption would have 
added significantly the $\delta^{13} \mathrm{C}_{\text {org }}$ flux observed in coastal environments near the PTB.

\section{Conclusion}

Organic carbon isotope trends of marine deposits of the Southern Alps PTB successions at Misci, San Antonio and Seis deviate by a distinct positive excursion from the carbonate $\delta^{13} \mathrm{C}$ just postdating the low-latitude marine event horizon. Spatially, organic carbon isotopes tend to heavier values with decreasing distance to the palaeocoastline, suggesting that enhanced continental influx transporting land plant material affected the bulk organic $\delta^{13} \mathrm{C}$ of marine sediments, particularly around the low-latitude mass extinction event. This spike of land plant-derived OM was likely caused by increased precipitation and runoff due to volcanic aerosols or by the ready removal of terrestrial plant material in the wake of rapid climatic and environmental change.

\section{Acknowledgements}

We acknowledge E. Kuhl (Berlin) for technical assistance, T. Algeo (Cincinnati) and M. Ruhl (Copenhagen) for the reviews and pertinent comments and the Freie Universität Berlin and the Museum für Naturkunde for contributions to financing this project and for providing the necessary facilities.

\section{Literature}

Algeo, T. J., Hannigan, R., Rowe, H., Brookfield, M., Baud, A., Krystyn, L. \& Ellwood, B. B. 2007. Sequencing events across the Permian-Triassic boundary, Guryul Ravine (Kashmir, India). - Palaeogeography, Palaeoclimatology, Palaeoecology 252: 328-346.

Algeo, T., Shen Ya-nan, Zhang Tong-gang, Lyons, T., Bates, S., Rowe, H. \& Nguyen, T. K. T. 2008. Association of ${ }^{34}$ S-depleted pyrite layers with negative carbonate $\delta^{13} \mathrm{C}$ excursions at the PermianTriassic boundary: Evidence for upwelling of sulfidic deep-ocean water masses. - Geochemistry Geophysics Geosystems 9: Q04025, doi:10.1029/2007GC001823.

Algeo, T., Henderson, C. M., Ellwood, B., Rowe, H., Elswick, E., Bates, S., Lyons, T., Hower, J. C., Smith, C., Maynard, B., Hays, L. E., Summons, R. E., Fulton, J. \& Freeman, K. H. 2012. Evidence for a diachronous Late Permian marine crisis from the Canadian Arctic region. - Geological Society of America Bulletin 124: 1424-1448, doi:10.1130/B30505.1

Arens, N. C., Jahren A. H. \& Amundson, R. 2000. Can C3 plants faithfully record the carbon isotopic composition of atmospheric carbon dioxide? - Paleobiology 26: 137-164, doi:10.1666/00948373(2000)026<0137:CCPFRT>2.0.CO;2.

Assereto, R., Bosellini, A., Fantini Sestini, N. \& Sweet, W. C. 1973. The Permian - Triassic boundary in the Southern Alps (Italy). In Logan, A. \& Hills, V. (eds). The Permian and Triassic Systems and their Mutual Boundary. - Canadian Society of Petroleum Geologists Memoir 2: 176-199.

Balme, B. E. 1979. Palynology of Permian-Triassic boundary beds at Kap Stosch, East Greenland. - Meddelelser om Grønland, udgivne af Komissionen for Videnskabelige Underrsøgelser i Grønland 200 (6): $1-37$.
Baud, A., Magaritz, M. \& Holser, W. T. 1989. Permian-Triassic of the Tethys: Carbon isotope studies. - Geologische Rundschau 78: 649-677.

Belcher, C. M., Mander, L., Rein, G., Jervis, F. X., Haworth, M., Hesselbo, S. P., Glasspool, I. J. \& McElwain, J. C. 2010. Increased fire activity at the Triassic/Jurassic boundary in Greenland due to climate-driven floral change. - Nature Geoscience 3: 426-429, doi:10.1038/ngeo871.

Berner, R. A. 2002. Examination of hypotheses for the Permo-Triassic boundary extinction by carbon cycle modeling. - Proceedings of National Academic Science of the United States of America 99: 4172-4177.

Bosellini, A. 1964. Stratigrafia, Petrografia e Sedimentologia delle Facies carbonatiche al limite Permiano-Trias nelle Dolomiti occidentali. - Estratto da "Memorie del Museo di Storia Naturale della Venezia Tridentina" 1964-65, Vol. XV, Fase. II: 106.

Brandner, R. 1988. The Permian-Triassic Boundary in the Dolomites (Southern Alps, Italy), San Antonio Section. - Berichte der Geologischen Bundesanstalt 15: 48-56.

Brandner, R., Horacek, M., Keim, L. \& Scholger, R. 2009. The Pufels/Bulla road section: Deciphering environmental changes across the Permian-Triassic boundary to the Olenekian by integrated litho-, magneto- and isotope startigraphy. A field trip guide. Geo.Alp 6: 116-132.

Cao Chang-qun, Yang Yun-chong, Shen Shu-zhong, Wang Wei, Zheng Quan-feng \& Summons, R. E. 2010. Pattern of $\delta^{13} C_{\text {carb }}$ and implications for geological events during the Permian-Triassic transition in South China. - Geological Journal 45: 186-194.

Chen Jin-shi, Shao Mao-rong, Huo Wei-guo \& Yao Yu-yuan 1984 Carbon isotope of carbonate strata at Permian-Triassic boundary in Changxing, Zhejiang. - Scientia Geologica Sinica 19 (1): 8893 (in Chinese with English abstract).

Chen Zhong-qiang \& Benton, M. J. 2012. The timing and pattern of biotic recovery following the end-Permian mass extinction. - Nature Geoscience 5: 375-383. doi:10.1038/NGEO1475.

Cirilli, S., Pirini Radrizzani, C., Ponton, M. \& Radrizzani, S. 1998. Stratigraphical and palaeoenvironmental analysis of the PermianTriassic transition in the Badia Valley (Southern Alps, Italy). Palaeogeography, Palaeoclimatology, Palaeoecology 138: 85-113.

Corsetti, F. A., Baud, A., Marenco, P. J. \& Richoz, S. 2005. Summary of Early Triassic carbon isotope records. - Comptes Rendus Palevol 4: 473-486.

Dal Corso, J., Preto, N., Kustatscher, E., Mietto, P., Roghi, G. \& Jenkyns, H. C. 2011. Carbon-isotope variability of Triassic amber, as compared with wood and leaves (Southern Alps, Italy). - Palaeogeography, Palaeoclimatology, Palaeoecology 302: 187-193, doi:10.1016/j.palaeo.2011.01.007.

Erwin, D. H. 1993. The Great Paleozoic Crisis: Life and Death in the Permian. Columbia University Press, New York

Erwin, D. H. 1994. The Permo-Triassic extinction. - Nature 367: $231-236$.

Erwin, D. H. 2006. Extinction - How life on Earth nearly ended 250 million years ago. Princeton University Press, Princeton and Oxford.

Farabegoli, E. \& Perri, M. C. 1998. Stop 4.3 - Permian/Triassic boundary and Early Triassic of the Bulla section (Southern Alps, Italy): Lithostratigraphy, facies and conodont biostratigraphy. Giornale di Geologia Ser. $3^{\mathrm{a}}$ (spec. issue, ECOS VII Southern Alps Fieldtrip Guidebook) 60: 292-311.

Farabegoli, E., Perri, M. C. \& Posenato, R. 2007. Environmental and biotic changes across the Permian-Triassic boundary in western Tethys: the Bulla parastratotype, Italy. - Global and Planetary Change 55: 109-135.

Faure, K., de Wit, M. J. \& Willis, J. P. 1995. Late Permian global coal hiatus linked to ${ }^{13} \mathrm{C}$-depleted $\mathrm{CO}_{2}$ flux into the atmosphere during the final consolidation of Pangea. - Geology 23: 507-510.

Fio, K., Spangenberg, J. E., Vlahović, I., Sremac, J., Velić, I. \& Mrinjek, E. 2010. Stable isotope and trace element stratigraphy across 
the Permian-Triassic transition: A redefinition of the boundary in the Velebit Mountain, Croatia. - Chemical Geology 278: 38-57.

Foster, C. B. 1982. Spore-pollen assemblages of the Bowen Basin, Queensland (Australia): their relationship to the Permian-Triassic boundary. - Review of Palaeobotany and Palynology 36: 165183.

Foster, C. B., Logan, G. A., Summons, R. E., Gorter, J. D. \& Edwards, D. S. 1997. Carbon isotopes, kerogen types and the Permian-Triassic boundary in Australia: Implications for exploration. - Australian Petroleum Production and Exploration Association Journal 37: 472-489.

Gorjan, P., Kaiho, K. \& Chen Zhong-qiang 2008. A carbon-isotopic study of an end-Permian mass-extinction horizon, Bulla, northern Italy: a negative $\delta^{13} \mathrm{C}$ shift prior to the marine extinction. - Terra Nova 20: 253-258.

Gorter, J. D., Foster, C. B. \& Summons, R. E. 1995. Carbon isotopes and the Permian-Triassic boundary in the north Perth, Bonaparte and Carnarvon Basins, Western Australia. - The Petroleum Exploration Society of Australia Journal 24: 21-38.

Grasby, S. E. \& Beauchamp, B. 2008. Intrabasin variability of the carbon-isotope record across the Permian-Triassic transition, Sverdrup Basin, Arctic Canada. - Chemical Geology 253: 141-150.

Grasby, S. E., Sanei, H. \& Beauchamp, B. 2011. Catastrophic dispersion of coal fly ash into oceans during the latest Permian extinction. - Nature Geoscience 4: 104-107, doi: 10.1038/NGEO1069.

Grice, K., Cao, Chang-qun, Love, G. D., Böttcher, M. E., Twitchett, R. J., Grosjean, E., Summons, R. E., Turgeon, S. C., Dunning, W. \& Jin, Yu-gan 2005. Photic zone euxinia during the PermianTriassic superanoxic event. - Science 307: 706-709.

Gröcke, D. R. 1998. Carbon-isotope analyses of fossil plants as a chemostratigraphic and palaeoenvironmental tool. - Lethaia 31: 113, doi:10.1111/j.1502-3931.1998.tb00482.x.

Gröcke, D. R., Hesselbo, S. P. \& Jenkyns, H. C. 1999. Carbon-isotope composition of Lower Cretaceous fossil wood: Ocean-atmosphere chemistry and relation to sea-level change. - Geology 27: 155158, doi:10.1130/0091-7613.

Hasegawa, T. 1997. Cenomanian-Turonian carbon isotope events recorded in terrestrial organic matter from northern Japan. - Palaeogeography, Palaeoclimatology, Palaeoecology 130: 251-273, doi:10.1016/S0031-0182(96)00129-0.

Hays, L. E., Beatty, T., Henderson, C. M., Love, G. D. \& Summons, R. E. 2007. Evidence for photic zone euxinia through the endPermian mass extinction in the Panthalassic Ocean (Peace River Basin, Western Canada). - Palaeoworld 16: 39-50.

Hermann, E., Hochuli, P. A., Bucher, H., Vigran, J. O., Weissert, H. \& Bernasconi, S. M. 2010. A close-up view of the PermianTriassic boundary based on expanded organic carbon isotope records from Norway (Trøndelag and Finnmark Platform). - Global and Planetary Change 74: 156-167, doi:10.1016/j.gloplacha.2010.10.007.

Hesselbo, S. P., Jenkyns, H. C., Duarte, L. V. \& Oliveira, L. C. V. 2007. Carbon-isotope record of the Early Jurassic (Toarcian) Oceanic Anoxic Event from fossil wood and marine carbonate (Lusitanian Basin, Portugal). - Earth and Planetary Science Letters 253: 455-470, doi:10.1016/j.eps1.2006.11.009.

Heydari, E., Arzani, N. \& Hassanzadeh, J. 2008. Mantle plume: The invisible serial killer -Application to the Permian-Triassic boundary mass extinction. - Palaeogeography, Palaeoclimatology, Palaeoecology 264: 147-162.

Holser, W. T. \& Magaritz, M. 1987. Events near the Permian-Triassic boundary. - Modern Geology 11: 155-180.

Holser, W. T., Schönlaub, H. P., Attrep, M., Boeckelmann, K., Klein, P., Magaritz, M., Orth, C. J., Fenninger, A., Jenny, C., Kralik, M., Mauritsch, H., Pak, E., Schramm, J. M., Stattegger, K. \& Schmöller, R. 1989. A unique geochemical record at the Permian/Triassic boundary. - Nature 337: 39-44.

Horacek, M., Brandner, R. \& Abart, R. 2007. Carbon isotope record of the P/T boundary and the Lower Triassic in the Southern Alps: evidence for rapid changes in storage of organic carbon. - $\mathrm{Pa}-$ laeogeography, Palaeoclimatology, Palaeoecology 252: 347-354.

Horacek, M., Povoden, E., Richoz, S. \& Brandner, R. 2010. High-resolution carbon isotope changes, litho- and magnetostratigraphy across Permian-Triassic Boundary sections in the Dolomites, NItaly. New constraints for global correlation. - Palaeogeography, Palaeoclimatology, Palaeoecology 290: 58-64, doi:10.1016/j.palaeo.2010.01.007.

Isozaki, Y. 1997. Permo-Triassic boundary superanoxia and stratified superocean: records from lost deep-sea. - Science 276: 235-238.

Knoll, A. H., Bambach, R. K., Canfield, D. E. \& Grotzinger, J. P. 1996. Comparative Earth history and late Permian mass extinction. - Science 273: 452-457.

Korte, C. \& Hesselbo, S. P. 2011. Shallow marine carbon and oxygen isotope and elemental records indicate icehouse-greenhouse cycles during the Early Jurassic. - Paleoceanography 26: PA4219, doi:10.1029/2011PA002160.

Korte, C. \& Kozur, H. W. 2005a. Carbon isotope stratigraphy across the Permian/Triassic boundary at Jolfa (NW-Iran), Peitlerkofel (Sas de Pütia, Sass de Putia), Pufels (Bula, Bulla), Tesero (all three Southern Alps, Italy) and Gerennavár (Bükk Mts., Hungary). - Journal of Alpine Geology 47: 119-135.

Korte, C. \& Kozur, H. W. 2005b. Carbon isotope trends in continental lake deposits of uppermost Permian to Lower Olenekian Germanic Lower Buntsandstein (Calvörde and Bernburg Formations). Hallesches Jahrbuch für Geowissenschaften B Beiheft 19: 87-94.

Korte, C. \& Kozur, H. W. 2010. Carbon isotope stratigraphy across the Permian-Triassic boundary: A review. - Journal of Asian Earth Sciences 39: 215-235.

Korte, C. \& Kozur, H. W. 2011. Temperature changes across the Permian-Triassic boundary and observations pertaining to some geological/geochemical features around this level. In Bhargava, O. N. (ed.). Facets of Phanerozoic (Collection of papers in honour of Prof. S.B. Bhatia). - Memoir Geological Society of India 78: $100-139$.

Korte, C., Veizer, J., Leythaeuser, D., Below, R. \& Schwark, L. 2001. Evolution of Permian and Lower Triassic $\delta^{13} \mathrm{C}$ in marine and terrigenous organic material. - Terra Nostra 2001/4: 30-34.

Korte, C., Kozur, H. W., Joachimski, M. M., Strauss, H., Veizer, J. \& Schwark, L. 2004a. Carbon, sulfur, oxygen and strontium isotope records, organic geochemistry and biostratigraphy across the Permian/Triassic boundary in Abadeh, Iran. - International Journal of Earth Sciences 93: 565-581.

Korte, C., Kozur, H. W. \& Mohtat-Aghai, P. 2004b. Dzhulfian to lowermost Triassic $\delta^{13} \mathrm{C}$ record at the Permian/Triassic boundary section at Shahreza, Central Iran. - Hallesches Jahrbuch für Geowissenschaften B Beiheft 18: 73-78.

Korte, C., Kozur, H. W. \& Partoazar, H. 2004c. Negative carbon isotope excursion at the Permian/Triassic boundary section at Zal, NW-Iran. - Hallesches Jahrbuch für Geowissenschaften B Beiheft 18: 69-71.

Korte, C., Pande, P., Kalia, P., Kozur, H. W., Joachimski, M. M. \& Oberhänsli, H. 2010. Massive volcanism at the Permian-Triassic boundary and its impact on the isotopic composition of the ocean and atmosphere. - Journal of Asian Earth Sciences 37: 293-311.

Kozur, H. W. 1998a. Some aspects of the Permian-Triassic boundary (PTB) and of the possible causes for the biotic crisis around this boundary. - Palaeogeography, Palaeoclimatology, Palaeoecology 143: $227-272$.

Kozur, H. W. 1998b. Problems for evaluation of the scenario of the Permian-Triassic boundary biotic crisis and of its causes. - Geologia Croatica 51/2: 135-162.

Kozur, H. W. \& Pjatakova, M. 1976. Die Conodontenart Anchignathodus parvus n. sp., eine wichtige Leitform der basalen Trias. Proceedings of the Koninklijke Nederlandse Akademie van Wetenschappen, Series B 79 (2): 123-128.

Kozur, H. W. \& Weems, R. E. 2010. The biostratigraphic importance of conchostracans in the continental Triassic of the northern 
hemisphere. In Lucas, S. G. (ed.). The Triassic timescale. - Geological Society, London, Special Publication 334: 315-417.

Krassilov, V. \& Karasev, E. 2009. Paleofloristic evidence of climate change near and beyond the Permian-Triassic boundary. - Palaeogeography, Palaeoclimatology, Palaeoecology 284: 326-336.

Kraus, S. H., Siegert, S., Mette, W., Struck, U. \& Korte, C. 2009. Stratigraphic significance of carbon isotope variations in the shallow-marine Seis/Siusi Permian-Triassic boundary section (Southern Alps, Italy). - Fossil Record 12 (2): 197-205.

Krull, E. S. 1999. Permian palsa mires as paleoenvironmental proxies. - Palaios 14: 530-544.

Krull, E. S. \& Retallack, G. J. 2000. $\delta^{13} \mathrm{C}$ depth profiles from paleosols across the Permian-Triassic boundary: Evidence for methane release. - Geological Society of America Bulletin 112: 1459-1472.

Krull, E. S., Retallack, G. J., Campbell, H. J. \& Lyon, G. L. 2000. $\delta^{13} C_{\text {org }}$ chemo stratigraphy of the Permian-Triassic boundary in the Maitai Group, New Zealand: Evidence for high-latitudinal methane release. - New Zealand Journal of Geology and Geophysics 43: 21-32.

Kump, L. R., Pavlov, A. \& Arthur, M. A. 2005. Massive release of hydrogen sulfide to the surface ocean and atmosphere during intervals of oceanic anoxia. - Geology 33: 397-400.

Magaritz, M. $1989 .{ }^{13} \mathrm{C}$ minima follow extinction events: a clue to faunal radiation. - Geology 17: 337-340.

Magaritz, M., Krishnamurthy, R. V. \& Holser, W. T. 1992. Parallel trends in organic and inorganic carbon isotopes across the Permian/Triassic boundary. - American Journal of Science 292: $727-739$.

Malkowski, K., Gruszczynski, M., Hoffman, A. \& Halas, S. 1989. Oceanic stable isotope composition and a scenario for the Permo-Triassic crisis. - Historical Biology 2: 289-309.

Michaelsen, P. 2002. Mass extinction of peat-forming plants and the effect on fluvial styles across the Permian-Triassic boundary, northern Bowen Basin, Australia. - Palaeogeography, Palaeoclimatology, Palaeoecology 179: 173-188.

Mostler, H. 1982. Bozener Quarzporphyr und Werfener Schichten. In Mostler, H. (ed.). Exkursionsführer zur 4. Jahrestagung der Österreichischen Geologischen Gesellschaft, Seis am Schlern, Südtirol, 1982. Innsbruck: pp. 43-79.

Naugolnykh, S. V. \& Zavialova, N. E. 2004. Densoisporites polaznaensis sp. nov. with comments on its relation to Viatcheslavia vorcutensis Zalessky. - Palaeobotanist 53 (1-3): 21-33.

Newell, A. J., Tverdokhlebov, V. P. \& Benton, M. J. 1999. Interplay of tectonics and climate on a transverse fluvial system, Upper Permian, Southern Uralian Foreland Basin, Russia. - Sedimentary Geology 127: 11-29.

Nielsen, J. K. \& Shen Ya-nan 2004. Evidence for sulfidic deep water during the Late Permian in the East Greenland Basin. - Geology 32: $1037-1040$.

Noé, S. 1987. Facies and Paleogeography of the Marine Upper Permian and of the Permian-Triassic Boundary in the Southern Alps (Bellerophon Formation, Tesero Horizon). - Facies 16: 89-142.

Nunn, E. V., Price, G. D., Gröcke, D. R., Baraboshkin, E. Y., Leng, M. J. \& Hart, M. B. 2010. The Valanginian positive carbon isotope event in Arctic Russia: Evidence from terrestrial and marine isotope records and implications for global carbon cycling. - Cretaceous Research 31: 577-592, doi:10.1016/j.cretres.2010.07.007.

Oberhänsli, H., Hsü, K. J., Piasecki, S. \& Weissert, H. 1989. Permian-Triassic carbon-isotope anomaly in Greenland and in the Southern Alps. - Historical Biology 2: 37-49.

Payne, J. L. \& Kump, L. R. 2007. Evidence for recurrent Early Triassic massive volcanism from quantitative interpretation of carbon isotope fluctuations. - Earth and Planetary Science Letters 256: 264-277.

Perri, M. C. 1991. Conodont biostratigraphy of the Werfen Formation (Lower Triassic) Southern Alps, Italy. - Bollettino della Società Paleontologica Italiana 30: 23-46.
Poole, I., Dolezych, M., Kool, J., van der Burgh, J. \& van Bergen, P. F. 2006. Do stable carbon isotopes of brown coal woods record changes in Lower Miocene palaeoecology? - Palaeogeography, Palaeoclimatology, Palaeoecology 236: 345-354, doi:10.1016/ j.palaeo.2005.11.013.

Posenato, R. 2008. Global correlations of mid Early Triassic events: The Induan/Olenekian boundary in the Dolomites (Italy). Earth-Science Reviews 91: 93-105.

Retallack, G. J. 1995. Permian-Triassic life crisis on land. - Science 267: 77-80

Retallack, G. J. \& Jahren, A. H. 2008. Methane Release from Igneous Intrusion of Coal during Late Permian Extinction Events. - Journal of Geology 116: 1-20.

Retallack, G. J., Jahren, A. H., Sheldon, N. D., Chakrabarti, R., Metzger, C. A. \& Smith, R. M. H. 2005. The Permian-Triassic boundary in Antarctica. - Antarctic Science 17: 241-258.

Riccardi, A., Kump, L. R., Arthur, M. A. \& D'Hondt, S. 2007. Carbon isotopic evidence for chemocline upward excursions during the end-Permian event. - Palaeogeography, Palaeoclimatology, Palaeoecology 248: 73-81.

Richoz, S. 2006. Stratigraphie et variations isotopiques du carbone dans le Permien supérieur et le Trias inférieur de la Néotéthys (Turquie, Oman et Iran). - Memoirs de Géologie (Lausanne) 46: 1-251.

Richoz, S., Krystyn, L., Baud, A., Brandner, R., Horacek, M. \& Mohtat-Aghai, P. 2010. Permian-Triassic boundary interval in the Middle East (Iran and N. Oman): Progressive environmental change from detailed carbonate carbon isotope marine curve and sedimentary evolution. - Journal of Asian Earth Sciences 39: 236-253.

Scholger, R., Mauritsch, H. J. \& Brandner, R. 2000. Permian-Triassic boundary magnetostratigraphy from the Southern Alps (Italy). Earth and Planetary Science Letters 176: 495-508.

Schönlaub, H. P. 1991. The Permian-Triassic of the Gartnerkofel-1 core (Carnic Alps, Austria): Conodont biostratigraphy. In Holser, W. T. \& Schönlaub, H. P. (eds). The Permian-Triassic boundary in the Carnic Alps of Austria (Gartnerkofel region). - Abhandlungen der Geologischen Bundesanstalt in Wien 45: 79-98.

Schwab, V. \& Spangenberg, J. E. 2004. Organic geochemistry across the Permian-Triassic transition at the Idrijca Valley, Western Slovenia. - Applied Geochemistry 19: 55-72.

Sephton, M. A., Looy, C. V., Veefkind, R. J., Brinkhuis, H., de Leeuw, J. W. \& Visscher, H. 2002. Synchronous record of $\delta^{13} \mathrm{C}$ shifts in the oceans and atmosphere at the end of the Permian. In Koeberl, C. \& MacLeod, K. G. (eds). Catastrophic Events and Mass Extinctions: Impacts and Beyond. - Geological Society of America Special Paper 356: 455-462.

Sephton, M. A., Looy, C. V., Brinkhuis, H., Wignall, P. B., de Leeuw, J. W. \& Visscher, H. 2005. Catastrophic soil erosion during the end-Permian biotic crisis. - Geology 33: 941-944.

Shen, J., Algeo, T. J., Zhou, L., Feng, Q., Yu, J. \& Ellwood, B. B. 2012a. Volcanic perturbations of the marine environment in South China preceding the latest Permian mass extinction and their biotic effects. - Geobiology 10: 82-103, doi:10.1111/j.14724669.2011.00306.x

Shen Jun, Algeo, T. J., Hu Qing, Xu Guo-zhen, Zhou Lian \& Feng Qing-lai 2012b. Volcanism in South China during the Late Permian and its relationship to marine ecosystem and environmental changes. - Global and Planetary Change, in press, doi:10.1016/ j.gloplacha.2012.02.011

Shen Jun, Algeo, T. J, Hu Qing, Zhang Ning, Zhou Lian, Xia Wenchen, Xie Shu-cheng \& Feng Qing-lai 2012c. Negative C-isotope excursions at the Permian-Triassic boundary linked to volcanism. - Geology 40: 963-966, doi: 10.1130/G33329.1.

Siegert, S., Kraus, S. H., Mette, W., Struck, U. \& Korte, C. 2011. Organic carbon isotope values from the Late Permian Seis/Siusi succession (Dolomites, Italy): Implications for palaeoenvironmental changes. - Fossil Record 14: 207-217. 
Sirevag, R., Buchanan, B. B., Berry, J. A. \& Troughton, J. H. 1977. Mechanisms of $\mathrm{CO}_{2}$ fixations in bacterial photosynthesis studied by the carbon isotope fractionation technique. - Archives of Microbiology 112: 35-38.

Svensen, H., Planke, S., Polozov, A. G., Schmidbauer, N., Corfu, F., Podladchikov, Y. Y. \& Jamtveit, B. 2009. Siberian gas venting and the end-Permian environmental crisis. - Earth and Planetary Science Letters 277: 490-500.

Takahashi, S., Kaiho K., Oba, M. \& Kakegawa, T. 2010. A smooth negative shift of organic carbon isotope ratios at an end-Permian mass extinction horizon in central pelagic Panthalassa. - Palaeogeography, Palaeoclimatology, Palaeoecology 292: 532-539.

Thomas, B. M., Willink, R. J., Grice, K., Twitchett, R. J., Purcell, R. R., Archbold, N. W., George, A. D., Tye, S., Alexander, R., Foster, C. B. \& Barber, C. J. 2004. Unique marine Permian-Triassic boundary section from Western Australia. - Australian Journal of Earth Sciences 51: 423-430.

Twitchett, R. J., Looy, C. V., Morante, R., Visscher, H. \& Wignall, P. B. 2001. Rapid and synchronous collapse of marine and terrestrial ecosystems during the end-Permian biotic crisis. - Geology 29: $351-354$.

Utting, J. 1994. Palynostratigraphy of Permian and Lower Triassic rocks, Sverdrup Basin, Canadian Arctic Archipelago. - Geological Survey of Canada, Bulletin 478: 1-107.

Visscher, H. 1971. The Permian and Triassic of the Kingscourt outlier, Ireland. - Geological Survey of Ireland, Special Paper 1: 1-114.

Visscher, H., Brinkhuis, H., Dilcher, D. L., Elsik, W. C., Eshet, Y., Looy, C. V., Rampino, M. R. \& Traverse, A. 1996. The terminal Paleozoic fungal event: Evidence of terrestrial ecosystem destabi- lization and collapse. - Proceedings of National Academic Science of the United States of America 93: 2155-2158.

Wacey, D., Wright, D. T. \& Boyce, A. J. 2007. A stable isotope study of microbial dolomite formation in the Coorong region, South Australia. - Chemical Geology 244: 155-174.

Ward, P. D., Montgomery, D. R. \& Smith, R. 2000. Altered river morphology in South Africa related to the Permian-Triassic extinction. - Science 289: 1740-1743.

Ward, P. D., Botha, J., Buick, R., De Kock, M. O., Erwin, D. H., Garrison, G. H., Kirschvink, J. L. \& Smith, R. 2005. Abrupt and gradual extinction among Late Permian land vertebrates in the Karoo Basin, South Africa. - Science 307: 709-714.

Watson J. S., Sephton M. A., Looy C. V. \& Gilmour I. 2005. Oxygencontaining aromatic compounds in a Late Permian sediment. Organic Geochemistry 36: 371-384, doi:10.1016/j.orggeochem.2004.10.006.

Whiticar, M. J. 1996. Stable isotope geochemistry of coals, humic kerogens and related natural gases. - International Journal of Coal Geology 32: 191-215.

Wignall, P. B. \& Hallam, A. 1992. Anoxia as a cause of the Permian/ Triassic mass extinction: facies evidence from northern Italy and the western United States. - Palaeogeography, Palaeoclimatology, Palaeoecology 93: 21-46.

Wignall, P. B. \& Twitchett, R. J. 1996. Oceanic anoxia and the end Permian mass extinction. - Science 272: 1155-1158.

Yin Hong-fu, Yang Feng-qing, Yu Jian-xin, Peng Yuan-qiao, Wang Shang-yan \& Zhang Su-xin 2007. An accurately delineated Permian-Triassic boundary in continental successions. - Science in China Series D: Earth Sciences 50: 1281-1292. 